\title{
Vejledning af adjunkter - oplevelse af og betingelser for faglig pædagogisk vejledning
}

Tina Bering Keiding, studielektor, Padagogisk Udviklingscenter, Aalborg Universitet.

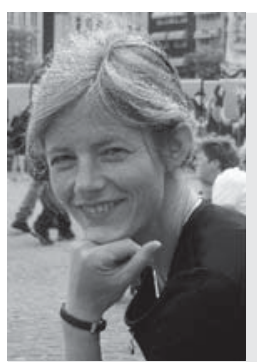

Tina Bering Keiding (f. 196I) er uddannet civilingeniør fra Aalborg Universitet og har fra samme sted en ph.d.-grad i teoretisk didaktik. TBK er ansat på Pædagogisk Udviklingscenter på Aalborg Universitet og som ekstern lektor på Høgskolen i Agder, Norge. Forskningsmæssigt arbejder TBK ud fra en systemteoretisk optik, blandt andet med genbeskrivelse af den almene didaktiks centrale begreber og problemorienteret projektorganiseret undervisning. Undervisningsmæssigt spænder opgaverne fra intern didaktisk efteruddannelse af universitetsansatte til undervisning af førsteårsstuderende i projekt- og gruppearbejde. Derudover en del eksternt rekvireret efteruddannelse.

Artiklen tilbyder en teoretisk og didaktisk refleksion over adjunkt-vejleder-interaktion. På baggrund heraf konkluderes, at eventuelle vanskeligheder med at tolke premisserne for interaktionen kan henge sammen med, at interaktionen ofte udfolder sig inden for en dobbeltkodning. Didaktisk analyse peger videre på, at vejledningsforlob, der konditioneres som mesterlare, dels scetter yderligere fokus på den personlige relation, dels forer til at adjunktens undervisning primart iagttages gennem mesteren. Endvidere argumenteres for, at mesterlare baserer sig på en entydighed i rigtige valg, som ikke modsvarer de krav til didaktisk kompetence, som adjunkten står overfor. Artiklen afrundes med skitsering af strategier for henholdsvis oplosning og håndtering af de beskrevne modsatninger.

\section{Baggrund og problemstilling}

I henhold til Cirkulære om stillingsstruktur for videnskabeligt personale ved universiteterne af 22. de- cember 2004, afsnit I.1. skal adjunkter på institutioner for videregående uddannelse modtage supervision og vejledning af egen undervisning. De fleste steder indfris dette krav gennem deltagelse $i$ et fagligt-pædagogisk uddannelsesforløb, ofte betegnet adjunktpædagogikum eller adjunktuddannelse. På tværs af institutionsspecifikke forskelle i omfang, form og indhold er flertallet af adjunktpædagogikum kendetegnet ved, at adjunkten i forbindelse med forløbet tilknyttes en eller evt. to vejledere; heraf en fra adjunktens eget faglige miljø ${ }^{1}$.

I forbindelse med kursusundervisning på adjunktpædagogikum på Aalborg Universitet og Handelshøjskolen i Århus har jeg gentagne gange hørt adjunkter fremsætte overvejelser om det modsætningsfyldte $i$, at de på den ene side skal lære om undervisning, blandt andet ved at forholde sig eksplicit til mindre vellykket undervisning sammen med en vejleder fra eget miljø, og på den anden side har brug for en positiv bedømmelse af deres undervisningskompetencer fra samme vejleder for at kunne søge en lektorstilling. Overvejelserne formuleres blandt andet gennem spørgsmål om, hvorvidt det ikke er for risikabelt at udstille sin usikkerhed over for vejlederen; om tematisering af eventuelle fiaskoer kan føre til, at man holdes ude, når undervisningen fordeles; om man gør klogt i at rette sig efter vejlederens råd i håb om at få en god bedømmelse; og om man - hvis man er grundlæggende uenig i de didaktiske og faglige råd, man făr fra sin vejleder - skal holde uenigheden for sig selv for at undgå en kritisk bedømmelse ${ }^{2}$. I en evaluering fra RUC omtales adjunkternes oplevelse af den universitetspædagogiske bedømmelse som en bekymrende konkurrenceparameter med uklare krav og betingelser (http://www. ruc.dk/upload/application/pdf/276a9ba1/uni-p_d.pdf, side 25).

Karakteren af den vejledningsrelation, som etableres i og med at adjunkten tildeles en vejleder, tematiseres kun i meget begrænset omfang i de anvisninger for 
vejledning/supervision, der findes på stort set alle landets adjunktpædagogikum (for henvisninger se næste afsnit). På RUC og på Økonomisk Institut, KU, beskrives vejledningsrelationen dog eksplicit som en mesterlærelignende relation (http://www.ruc.dk/unipaed/ adjunktuddannelsen/adjunktvejleder/; http://www. econ.ku.dk/ispu/Materiale/ISPUnotater/notat1.pdf), mens det på AAU præciseres, at der tilstræbes ligeværdighed eller principiel symmetri mellem deltagerne (http://www.puc.aau.dk/Adjunkt2005/supervision/ Vejledning_supervision_2005.pdf). Sidstnævnte hindrer dog ikke adjunkterne $i$ at beskrive vejledningsforholdet som præget af usikkerhed og uklare forventninger.

Hensigten med dette bidrag er at foretage en teoretisk analyse af den skitserede problemstilling. Mit ærinde er altså hverken at foretage en systematisk beskrivelse og analyse af adjunkternes oplevelser eller vurdere omfanget af problemet, men udelukkende at bidrage til at begribe et fænomen, som jeg gennem årene har hørt tematiseret af en del adjunkter.

\section{Teori og metode}

Med udgangspunkt i Niklas Luhmanns teori består sociale systemer af kommunikation (Luhmann 1995b, Luhmann 2000), hvor én kommunikationsenhed består af tre selektioner. De to første selektioner er den meddelendes valg af information og meddelelse; det vil sige hvad og hvordan, der skal meddeles. Den tredje og sidste selektion er adressatens valg af forståelse; altså hvordan det meddelte forstås (Luhmann 1995b). I overensstemmelse med det teoretiske blik betragtes vejledning her $i$ artiklen som et socialt system bestånde af kommunikationen mellem adjunkt og vejleder. Endvidere betragtes vejledning som en variationsform af undervisning, som med Luhmann kan beskrives som den særegne form for kommunikation, der tilstræber at forandre psykiske systemer til det bedre (fx Luhmann 2002, $105 \&$ 143). Det betyder, at undervisning og dermed også vejledning altid baserer sig på en forestilling om, at nogle forandringer er bedre end andre.

Luhmann skelner skarpt mellem læring som forandring af psykiske systemers strukturer og undervisning som kommunikation. Da han endvidere antager, at systemer fungerer selvreferentielt (autopoietisk), må man med Luhmann som referencepunkt afvise enhver antagelse om, at undervisning kan gribe kausalt ind i de lærendes psykiske system. Det betyder ikke, at undervisning ikke kan bidrage til læring. Som al anden kommunikation kan undervisningen stimulere og pirre psykiske systemer. Præmissen om systemers selvreference peger blot på, at forholdet mellem undervisning og læring ikke kan forstås som simpel kausalitet. Tilsvarende kan undervisningen ikke iagttage psykiske systemers læring direkte, dvs. som bevidsthedsoperationer, men må stille sig tilfreds med at udtale sig om læring på baggrund af forståelse af deltagernes kom- munikative bidrag. (Keiding 2005,158-161; Luhmann 2000,151-152). Konkret betyder det, at en deltager kan have lært det, undervisningen tilstræber, men meddeler sin læring på en måde, som undervisningen forstår som udtryk for ikke-læring. Dette har jeg dels hørt tematiseret i forbindelse med den øgede brug af portfolio-metoden i professionsuddannelser, hvor nogle studerende har vanskeligt ved at udtrykke sig skriftligt og dermed kommer til af fremstå som mindre dygtige, dels har jeg for nylig selv oplevet en markant modsætning mellem en adjunkts meget kvalificerede mundtlige refleksioner og hans portfolio, hvori han for første gang forsøgte at udtrykke sig skriftligt på dansk. For en systemteoretisk refleksion over portfolio-metodikken se Keiding (2002).

Undervisning baserer sig i vid udstrækning på interaktion; det vil sige på den type af kommunikation, hvor deltagerne kan behandles som nærværende og gensidigt fornemmer hinanden (Luhmann 2000:474f, 520; Luhmann 2002,56-57). Anvendelse af kommunikationsbegrebet i relation til undervisning gør det relevant at skelne mellem synkron interaktion og asynkron interaktion. Synkron interaktion beskriver interaktion, hvor deltagerne er nærværende gennem fysisk tilstedeværelse og forståelse. Dermed vælges samtidigt/synkront med den meddelte information, mens asynkron interaktion beskriver interaktion, hvor deltagerne er nærværende, men ikke fysisk tilstede.Valg af forståelse sker da forskudt i tid og rum (Keiding 2005,203-204). I adjunktpædagogikum vil begge interaktionsformer formodentlig være aktuelle. Med mindre det er relevant at betone, hvilken kommunikationsform der er tale om, anvender jeg blot betegnelsen interaktion. Valget af benævnelsen interaktion frem for den mere almene betegnelse kommunikation sker for at understrege, at det, at deltagerne er nærværende for hinanden, for mig at se er et centralt karakteristika ved vejledning som kommunikationsform. Det er ikke en vilkårlig og fjern, men netop en helt bestemt og nærværende person, der observerer og bedømmer adjunkten.

Valgmulighederne for kommunikative hændelser vil oftest være ordnede på en måde, som indsnævrer meningshorisonten (Luhmann 2000,60). Nogle temaer, nogle måder at meddele sig på og nogle forståelser af det meddelte vil dermed være mere forventelige end andre. For eksempel vil horisonten for sandsynlige kommunikative valg således være grundlæggende forskellige afhængigt af, om interaktionen konditioneres (rammesættes) af differencen lærer/elev eller af differencen forældre/barn.

Meningshorisonten konstitueres ifølge Luhmann (2000,102-115) i tre dimensioner: en sags-, en socialog en tidsdimension. De tre dimensioner peger på, at en aktuel mening/betydning formes af, både hvad der kommunikeres om, hvem der deltager i kommunikationen, og hvornår det sker. Når jeg i artiklen anvender begrebet relation, sker det for at understrege, at de 
kommunikative bidrag i en vejledningssituation ikke kun ordnes tema- og tidsmæssigt (hvad der kan tales om hvornår), men at nogle temaer forbindes tættere til nogle personer end andre (hvem der kan tale om hvad) og dermed bidrager til at konstituere en bestemt rolle for personerne. I undervisning synes det eksempelvis umiddelbart muligt for både elev og lærer at tematisere, hvordan man sætter kommaer, men formodentlig mindre muligt for eleven at bedømme lærerens komma-kompetence end omvendt. Denne forskel kan netop tilskrives, at interaktionen blandt andet kan karakteriseres ved en bestemt rollefordeling. Eller med andre ord ved en bestemt relation mellem de deltagende personer. Relation henviser derfor ikke til ontologiske eller følelsesmæssige træk ved en given interaktion, men til en aktuel, systemrelativ - og kontingent - tildeling af sociale roller. I undervisning og vejledning, hvor det ikke er tydeligt, hvad der skal læres, synes socialdimensionen at fă afgørende indflydelse på den aktuelle meningshorisont, fordi præmisserne for hvad og hvordan, der kan kommunikeres, ikke kan bestemmes ved henvisning til noget uden for kommunikationen, men må bestemmes blandt andet gennem henvisning til, hvem der siger det.

Meningshorisontens tidsdimension henviser til, at det med stor sandsynlighed ikke er fuldkommen vilkårligt, hvornår noget tematiseres. Nogle tidspunkter fremstår med andre ord mere oplagte og velvalgte for aktualisering af et givet tema end andre. Undervisning betjener sig i vid udstrækning af en sådan tidslig ordning. Der foretages eksempelvis ikke standpunktsbedømmelse, før eleverne har haft mulighed for at arbejde med det aktuelle tema. Og hvis der foretages en bedømmelse på et tidligere tidspunkt, understreger kommunikationen, at der er tale om en særlig form for bedømmelse, som udelukkende tjener undervisnings- og læringsmæssige hensigter.

Artiklens datagrundlag er, ud over de indtryk fra kursusundervisning jeg indledningsvist refererer til, beskrivelser af retningslinjer for samt evalueringer af adjunktpædagogikum fra en række af landets universiteter. Primært:

- http://www.sdu.dk/Adm/CFE/adjped.shtml

- http://www.learninglab.dtu.dk/upload/institutter/dtv/llab_dtu_ publikationer/teacher_traning_2006.pdf

- http://www.1l.cbs.dk/pdf_filer/AUK_Regelsæt_2006.pdf

- http://www.puc.aau.dk/Adjunktkursus.htm

- http://www.puc.aau.dk/Adjunkt2006/docs/Kursusbeskrivelse_2006.pdf

- http://www.puc.aau.dk/Adjunkt2005/supervision/Vejledning_ supervision_2005.pdf

- http://www.asb.dk/inline/forskning/adjunkt.aspx

- http://www.asb.dk/upload/asb/inline/forskning/docs/ om\%20praktikvejledning.pdf

- http://www.ruc.dk/unipaed/adjunktuddannelsen/

- http://www.ruc.dk/unipaed/adjunktuddannelsen/ adjunktpaedagogikum/\#praktisk

- http://www.hum.au.dk/cfu/sider/indsatsomraader/adjunktpaedagogikum.htm
- http://www.hum.au.dk/cfu/sider/indsatsomraader/ressourcer/ regler_adjunktuddannelse.DOC

- http://www.cnd.ku.dk/side22615.htm?lang=3\#Faglig-pædago gisk $\% 20$ vejledning $\% 20$ og $\% 20$ supervision

- http://www.econ.ku.dk/ispu/Materiale/ISPUnotater/notat1. pdf

Materialet iagttages gennem, hvad der i forhold til artiklens problemstilling fremstår som to centrale og overordnede ledeforskelle, nemlig forskellen tillid/mistillid samt forskellen adjunkt-vejlederrelationen/alt andet. Inden for hvert af de to temaer, som ledeforskellene angiver, iagttages det empiriske materiale med henblik på at beskrive, hvilke forskelle der synes anvendt. Ideen bag metoden er, at enhver betegnen af noget baserer sig på markering af en forskel. Forskelle kan ifølge Luhmann markeres på to forskellige måder. Enten ved at det betegnede skelnes fra andet, eller ved at det betegnede skelnes fra noget, som også betegnes. I førstnævinte tilfælde fremstår det betegnede som et objekt, $i$ andet tilfælde som et begreb (Luhmann 1995a). Når der eksempelvis i en studieordning står "den studerende skal ...", sker betegnelsen af den studerende ved, at den studerende skelnes fra alt andet, dvs. gennem anvendelse af forskellen studerende/-. En formulering som »de studerendes bidrag til undervisningen er at... synes derimod at benytte forskellen studerende/underviser og bidrager herigennem til at fastlægge, hvilke ydelser i undervisningen der forventes af de forskellige deltagere. Tilsvarende antyder en formulering som "Vejleder og supervisor bedømmer adjunktens undervisningskompetence« grundlag for at beskrive vejlederens relation til adjunkten gennem forskellen eksaminator/alt andet. (For yderligere beskrivelse af den analytiske metode henvises til Keiding 2005, 197-246).

\section{Tillid}

Med en Luhmann-inspireret tilgang kan tillid anskues som en mekanisme til reduktion af social kompleksitet (Luhmann 1999:140). Pointen hos Luhmann er, at kommunikation potentielt er risikabel, fordi deltagerne grundlæggende ikke kan forudsige andres valg og handlinger. Samtidig må en konstant tematisering af denne usikkerhed og justering af kommunikative handlinger i henhold hertil opgives, fordi dette vil belaste sociale systemer i et sådant omfang, at de "næppe [ville] blive dannet ud over i en meget snæver og kortfristet forstand (Luhmann 2000,169).

Dannelse af stabile sociale systemer, der temamæssigt beskæftiger sig med andet end betingelserne for egen beståen, kræver derfor mekanismer eller strategier for håndtering af kommunikationens potentielle usikkerhed. Og netop her byder differencen tillid/mistillid sig til. Den sociale usikkerhed kan med andre ord reduceres gennem enten tillid eller mistillid.

Det synes indlysende, at tillid som strategi har langt større rækkevidde i forhold til at skabe orden og der- 
for aflaster det sociale system langt mere end mistillid (Luhmann 1999:125; Luhmann 2000:168-170). Ganske enkelt fordi tillidsstrategien fritager det sociale system for løbende at skulle beskæftige sig med kommunikationens betingelser og muligheden for skuffelse. Hvis usikkerheden håndteres gennem mistillidsstrategien, må kommunikationen løbende fastlægge og reflektere betingelserne for dens egen beståen.

Udsagn af typen "Er det mon risikabelt at fortælle om sine fiaskoer«, "Gør man klogest $i$ at følge vejlederens råd, selv om man er uenig«, henviser for mig at se til differencen tillid/mistillid. Ikke i betydningen at adjunkterne udtrykker mistillid til deres vejleder, men ved at de spørger til, hvorvidt og i hvilket omfang og inden for hvilke temaer interaktionen med vejlederen uden alt for stor risiko kan baseres på tillid. De er med andre ord opmærksomme på, at blind tillid - også i denne sammenhæng - kan være »dumt, uønsket og skadeligt« (Luhmann 2000:169) og forholder sig i lyset heraf refleksivt til grænsen mellem tillid og mistillid i adjunkt-vejleder-relationen.

\section{Studerende eller kollega?}

Behovet for at forholde sig refleksivt til denne grænse hænger for mig at se nøje sammen med nogle af de præmisser, der bidrager til konditionering af adjunktvejleder-interaktionen.

Interaktionen mellem adjunkten og dennes vejleder rummer på den ene side en række træk fra den interaktionsform, man meget alment kan betegne som undervisning. Det at fă tildelt en vejleder er tæt forbundet med at være undervejs, under uddannelse og dermed $\mathrm{i}$ den lærendes rolle. Som interaktionsform er undervisning, herunder vejledning, baseret på forventning om kundskabsmæssig asymmetri inden for undervisningens genstandsfelt; en asymmetri som i udgangspunktet altid vender sådan, at det er underviseren, der ved, mens den vejledte forventes at påtage sig rollen som den lærende (Luhmann 2002:107-108). Endvidere er det en nærmest indbygget præmis, at underviseren gennem anvendelse af differencen bestået/ikke bestået træffer beslutninger om den lærendes fortsatte medlemskab af uddannelsen eller ophør af samme (Luhmann 2002:70-72; Luhmann 2004:29f). Gennem anvendelse af denne difference bliver det også klart, at al undervisning får ende. Interaktionens afslutning er med andre ord besluttet, førend den begynder (se hertil eventuelt Luhmann 1995a).

Disse karakteristika ved undervisning og vejledning kan anvendes til konditionering af kommunikationen. Ved at konditionere interaktionen gennem forskellen undervisning/alt andet kan adjunkten - i hvert fald indtil andet viser sig at være tilfældet - således have tillid til, at den person, der gennem konditioneringen tildeles rollen som vejleder, vil vejlede og slutteligt bedømme, samt at vejlederen har faglige og/eller meto- diske forudsætninger, der bidrager til kundskabsmæssig asymmetri.

På den anden side udfolder interaktionen mellem adjunkt og vejleder sig under betingelser, som gør den grundlæggende forskellig fra undervisning. Det vil oftest være sådan, at adjunktpædagogikum ikke har samme tidslige udstrækning som adjunkturet, men snarere indgår som en delaktivitet i dette. Det betyder, at interaktionen mellem adjunkten og den pågældende vejleder ofte både op til, under og efter adjunktpædagogikum kan forventes konditioneret af differencen kolleger/alt andet.

Ganske som differencen undervisning/alt andet kan differencen kolleger/alt andet bidrage til konditionering af interaktionen og aktualisere forventninger til, hvad man kan forvente, og dermed hvad der kan håndteres, gennem tillidsbaserede strategier. Nogle af disse forventninger kan gå på blandt andet faglig symmetri, anerkendelse af den anden som legitimt medlem af organisationen ${ }^{3}$ samt fravær af formaliserede sanktionsmuligheder, hvad angår inklusion $i$ og eksklusion fra organisationen. Som kollega kan man med andre ord forvente at blive betragtet som et fagligt kompetent og legitimt medlem af en given organisation. Kollegialitet synes således at betone meningshorisontens sags- og socialdimension. Hermed ikke sagt, at tidsdimensionen ikke spiller nogen rolle for meningshorisonten. Snarere er et særligt og i denne sammenhæng væsentligt træk ved kollegarelationer, at tidsdimensionen konstituerer en åben tidshorisont. Det er i mange tilfælde, måske endda oftest, ikke entydigt besluttet, hvornår relationen ophører. På den måde bliver tiden virksom i konstruktionen af meningshorisonten gennem kollegarelationens potentielt langvarige udstrækning. Kolleger må derfor til stadighed have øje for, at interaktionen udvikler sig således, at der ikke opstår hændelser, som vanskeliggør den fortsatte kommunikation i en sådan grad, at den kollegiale relation må bringes til ophør for tid.

Tidsdimensionen synes at kunne få afgørende betydning for kollegial interaktion i de tilfælde, hvor nogle deltageres medlemskab ikke entydigt baserer sig på en åben tidshorisont. Man er måske nok kolleger, men kolleger på forskellige betingelser. Dette forhold aktualiseres på to måder i adjunktpædagogikum. For det første gennem den afsluttende bedømmelse (bestået/ikke bestået), som tematiserer, at adjunkten kun kan forblive som kollega og blive kollega på lige betingelser, hvis bedømmelsen falder positivt ud. For det andet at denne mulighed kun kan aktualiseres, hvis organisationen vælger at opslå en lektorstilling inden for et relevant område.

\section{Vejledningsrelationens dobbeltkodning}

Når en adjunkt påbegynder sit adjunktpædagogikum og tildeles eller vælger en kollega som vejleder og be- 
dømmer, kan man med udgangspunkt i ovenstående argumentere for, at interaktionen går fra at være konditioneret af forskellen kolleger/alt andet til at være konditioneret af to forskelle, nemlig undervisning/alt andet og kolleger/alt andet. Der aktualiseres med andre ord på en og samme tid to meningshorisonter, som adskiller sig afgørende fra hinanden gennem tildeling af sociale roller. Interaktionen udsæettes dermed for en dobbeltkodning/dobbelt konditionering, hvilket bidrager til at gøre den mere ubestemt. Hermed bliver det mindre tydeligt, hvilke aspekter af interaktionen der kan baseres på tillid, og hvilke der må håndteres gennem mistillid. Dette fremgår eksempelvis af følgende citat, som stammer fra en deltager i AAU's adjunktpædagogikum. I citatet forholder personen sig til temaet kollegial supervision og beskriver kollegial supervision gennem en modstilling mellem kollegial supervision og adjunktpædagogikum: »]eg deltog [... i kollegial supervision...] og det var en kolossal positiv oplevelse. Sammenlignet med andre pædagogiske uddannelses- og udviklingsforløb, jeg har deltaget i-dvs. f.eks. handelsskolens pædagogikum og pædagogikumvejlederuddannelse samt universitetets adjunktpædagogikum - har den kollegiale supervision den store fordel, at man i en mere fri, tryg og 'demokratisk' kontekst kan eksperimentere med, reflektere over og udvikle sin undervisning. Man kommer således ud over den forestilling af kontrol og vurdering, der - begrundet eller ubegrundet - mange steder skaber modstand mod pædagogisk udviklingsarbejde" (http://www.hum. au.dk/cfu/sider/indsatsomraader/erfaringer/psl_erfaringer_supervision.htm).

Den usikkerhed om præmisserne for interaktionen med vejlederen, som jeg har hørt, adjunkter giver udtryk for, kan tolkes som udtryk for, at det ikke er indlysende, hvordan de to kontekster (henholdsvis undervisning/alt andet og kolleger/alt andet) forholder sig til hinanden. Er referencepunktet (konteksternes kontekst ${ }^{4}$, at man er kolleger, hvor den ene så lejlighedsvis tilbyder kollegial vejledning og gode råd og til slut skriver en positiv bedømmelse? Eller er referencepunktet snarere differencen undervisning/alt andet, således at adjunkten også uden for de formaliserede vejledningssituationer iagttages og oplever sig som en, der skal lære, bedømmes og godkendes? Eller er det snarere sådan, at adjunkten ikke helt kan beslutte, hvordan han eller hun skal kategorisere relationen og dermed primært opfatter den som uklar og/eller modsætningsfyldt?

Den samtidige aktualisering af to grundlæggende forskellige konditionerende forskelle kan således føre til manglende entydighed $i$, hvordan interaktionen med og relationen til den anden skal tolkes, og dermed tvivl om, hvad der kan anskues som meningsfulde handlinger. Dette gælder for så vidt både adjunkt og vejleder, men fokus i denne artikel ligger entydigt på adjunkten. Adjunkternes refleksive iagttagelser af betingelserne for interaktionen med og relationen til vejlederen kan derfor ses som et forsøg på at få ordnet de to differencer og tilhørende kontekster i forhold til hinanden for derigennem at etablere en meningshorisont, som bidrager til at identificere, hvad adjunkten kan have tillid til $\mathrm{i}$ interaktionen med vejlederen, og hvad der må håndteres gennem mistillid.

Mit indtryk fra samtaler med adjunkter, der tematiserer, hvordan interaktionen med vejlederen skal håndteres, er, at det forhold, at vejlederen oftest også er bedømmer, og dermed kan komme til at fungere som gatekeeper i forhold til videre karriere i forskningsverdenen, vejer tungest, når forholdet mellem de to konditionerende forskelle skal fastlægges. Det forudgående citat antyder ligeledes, at bedømmelsesfunktionen får afgørende betydning for interaktionen. Adjunkten bliver altså studerende først og kollega næst i bestræbelserne på at blive bedømt som en god underviser. Men hvad er kriterierne for en sådan bedømmelse?

\section{Et didaktisk blik på adjunkt- vejleder-relationen}

Fælles for flertallet af de videregående uddannelsers adjunktpædagogikum er, at vejlederen fra adjunktens faglige miljø også fungerer som bedømmer. Eventuelt sammen med en pædagogisk/didaktisk vejleder. Denne model svarer nøje til, hvad der kendes fra vejledning andre steder i uddannelsessystemet.

Der hvor jeg ser en afgørende forskel i forhold til formaliseret uddannelse er det udprægede fravær af transparente bedømmelseskriterier.

I formaliseret uddannelse, bidrager mere eller mindre klart formulerede studieordninger til en vis transparens ved at angive, hvad den lærende bedømmes på, og dermed hvad uddannelsens kriterier for bestået eksamen er. Tilsvarende kriterier forekommer enten ikke eller kun i meget løse formuleringer i adjunktpædagogikum, hvilket betyder, at bedømmelsen i vid udstrækning kommer til at referere til vejlederens/vejledernes personlige kriterier for god undervisning. Eksempelvis: »Evalueringens grundlag består af: En skriftlig rapport fra vejlederen (omkring 1 side) med vejlederens generelle indtryk af adjunktens pædagogiske indsats og kvalifikationer. En selvevaluering rummende adjunktens pædagogiske overvejelser før, under og efter forløbet (3/5 sider). De studerendes midtvejs- og slutevalueringer af adjunktens kurser i de to vejledningssemestre" (http://www.hum.au.dk/cfu/ sider/indsatsomraader/ressourcer/regler_adjunktuddannelse.DOC). Eller: "Vejleder og supervisor bedømmer adjunktens undervisningskompetence. [...] Bedømmelsen foretages af vejleder og supervisor på følgende grundlag: 1.Vejleder og supervisors observationer af adjunktens undervisning. 2. Bearbejdet portfolio [...] 3. Adjunktens opgave. 4. Pædagogisk 
CV. 5. Studenterevalueringer 6. Evt. andre typer evaluering af undervisning, ledelse af undervisning og af undervisningsmaterialer" (http://www.ll.cbs. dk/pdf_filer/AUK_Regelsæt_2006.pdf).

Transparente kriterier ændrer selvsagt ikke ved det forhold, at det er vejleder/eksaminator, der vurderer en aktuel præstation og gør dette med mere eller mindre klar reference til de aktuelle kriterier, men gør det dog muligt for andre - herunder den vurderede - at vurdere vurderingen ved at spejle den i kriterierne.

Det, at en bedømmelse refererer til vejlederens ikke-synlige, personlige kriterier, betoner den personlige dimension i relationen mellem adjunkt og vejleder. Der sættes med andre ord ekstra fokus på, hvem der siger og gør hvad i interaktionen. Dermed får socialdimensionen en afgørende betydning i frembringelse af den aktuelle meningshorisont. En sådan undervisnings- og bedømmelsespraksis kendes blandt andet fra mesterlæretraditionen (Lave \& Wenger, 1991; Nielsen \& Kvale 1999,16). For en systematisk og gennemgribende eksamination af disse præmisser, se Munk (2002).

At adjunktpædagogikum rummer mesterlærelignende træk, fremgår for nogle institutioners vedkommende implicit gennem beskrivelse af vejlederfunktion og bedømmelseskriterier, eksempelvis gennem brugen at betegnelsen rollemodel (http://www.asb.dk/inline/ forskning/adjunkt.aspx). Andre steder fremhæves mesterlæreprincippet eksplicit: "Der er altså tale om en slags mesterlæresystem, hvor adjunkten skal have mulighed for at gøre erfaringer med diverse undervisningsog evalueringsformer. Adjunktens undervisning og vejledning skal overværes og diskuteres, ligesom adjunkten skal have mulighed for at overvære en erfaren universitetslærers undervisning og vejledning. Afsluttende skal adjunkterne have en skriftlig bedømmelse af deres undervisningsmæssige kvalifikationer" (http://www.ruc. $\mathrm{dk} /$ unipaed/adjunktuddannelsen/adjunktvejleder/).

(Eventuelt også http://www.econ.ku.dk/ispu/Materiale/ISPUnotater/notat1.pdf (side 4) og http://www. ruc.dk/upload/application/pdf/276a9ba1/uni-p_d.pdf (side 23)).

\section{Mesterlære som didaktisk teori}

I det følgende vil jeg se lidt nærmere på mesterlære som didaktisk teori ${ }^{5}$. Her vil jeg tage afsæt i den didaktiske trekant, som kan anvendes til at tydeliggøre, hvordan forskellige former for undervisning betoner forskellige aspekter af interaktionen (Künzli, 1998). Dermed kan modellen også anvendes som analyseramme for refleksion over og sammenligning af forskellige didaktiske teorier (Keiding 2005, 30f). Nedenstående figur illustrerer dette gennem indplacering af fă udvalgte teorier, som jeg vurderer har almen relevans for dansk didaktik. I Künzli (2000) foretages en tilsvarende indplacering af udvalgte teorier fra den tyske didaktik.

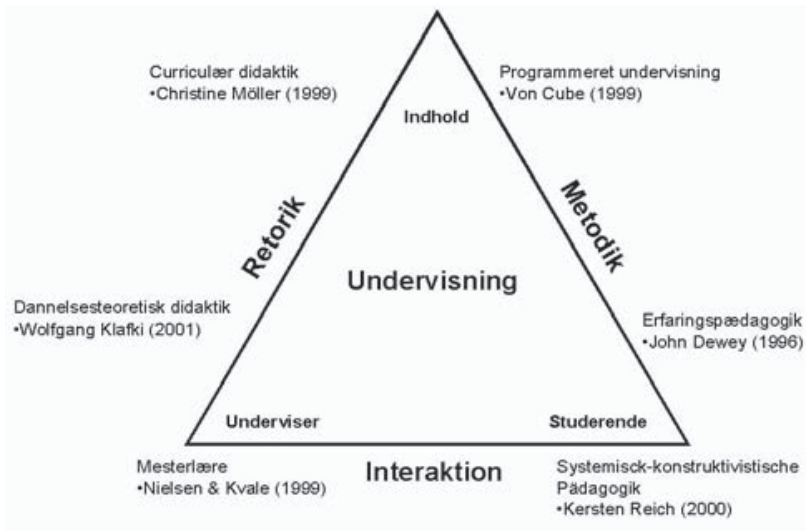

Figur 1. Den didaktiske trekant som analysemodel for identifikation af udvalgte didaktiske teoriers differentieringsforsog. Navn og årstal henviser til en reference på pågaldende position.

Modellens analytiske potentiale ligger $i$, at den i al sin enkelhed forholder sig til tre centrale variable i undervisende kommunikation, herunder vejledning, nemlig det forhold at en lærende skal lære sig noget bestemt med kommunikativ støtte fra en underviser.

Både undervisning som interaktion og didaktiske teorier har tendens til at forskyde opmærksomheden mod én af de tre akser. Hermed markeres ét aspekt af undervisningen frem for andre. Som for alle andre iagttagelser gælder, at markering af noget lader noget andet fremstå umarkeret. Den side i den didaktiske trekant, som opmærksomheden rettes mod, tildeles gennem iagttagelsen status som undervisningens moment, mens de aspekter af interaktionen, som beskrives gennem trekantens øvrige sider, fremstår uiagttagede. Forskydning i opmærksomhed mod en af trekantens akser eller et af de tre hjørner bidrager derfor til reduktion af kompleksitet $i$ beskrivelse af undervisning. Samtidig etablerer forskydningen i opmærksomhed de øvrige sider og hjørner som undervisningens blinde plet (Keiding 2005:32).

Der er afgørende forskelle på, hvilke aspekter af interaktionen en given undervisning eller didaktisk teori retter blikket imod. Forskydningen i opmærksomhed kan derfor anvendes til at fastlægge, hvad jeg vil betegne som undervisningens/teoriens differentieringsforsøg. Ved at indplacere en given teori på en af trekantens sider eller $i$ et af dens hjørner, bliver det samtidig tydeligt, hvilke aspekter af undervisningen som tildeles mindre opmærksomhed. Undervisning, hvor fokus altovervejende ligger på formidling af indhold - for eksempel ved en forelæsning - har således tilbøjelighed til at nedtone refleksioner over og opmærksomheden på adressaterne for dette indhold.

Undervisning og didaktiske teorier betoner i nogle tilfælde underviserens fremstilling af indhold og placerer sig dermed analytisk på den side i trekanten, som Künzli betegner retorikaksen. Undervisning ses her primært som underviserens formidling af indhold til den lærende. På denne akse kan indholdet så gives 
forrang for underviseren eller omvendt. Analytisk sker det ved at forskyde referencepunktet for didaktiske valg mod henholdsvis et forud givet indhold eller mod underviserens valg af indhold. Med dette differentieringsforsøg forskydes opmærksomheden væk fra den lærende som adressat for den meddelte information. Den lærende bliver dermed undervisningens/teoriens blinde plet.

Fokus i undervisning og didaktiske teorier kan også betone, hvordan den lærende skal møde og arbejde med indholdet, og placerer sig dermed på trekantens metodikakse. Også her kan referencepunktet for valg forskydes mod den ene eller anden ende af aksen. Indholdet kan gives forrang for den lærende, sådan som det kendes fra programmeret undervisning, mens erfaringspædagogiske tiltag betoner den lærendes valg og prægning af undervisningens indhold. Undervisning og didaktiske teorier, som fokuserer på relationen mellem undervisningens indhold og den lærende, etablerer samtidig underviseren og underviserens funktion som kommunikationens blinde plet.

Endelig kan relationen mellem underviser og lærende være $\mathrm{i}$ fokus. Referencepunktet for didaktiske valg kan her forskydes enten mod underviseren eller mod den lærende. Künzli betegner disse to muligheder som henholdsvis en karismatisk og en demokratisk tolkning af interaktionen (Künzli 1998, 37).

I forhold til adjunktvejledning vil vejledningen $\mathrm{i}$ en demokratisk fortolkning af interaktionen tage afsæt $i$ adjunktens indsigter, erfaringer og vurderinger af egen undervisning. Der tilstræbes med Künzlis (1998:37) ord en quasi-symmetrisk interaktion. Et eksempel herpå findes i AAUs anvisninger for adjunktvejledning: "For både den, der bliver superviseret, og supervisor er der tale om, at de i supervisionssituationen i første omgang hver for sig danner sig et billede af den gennemforte undervisning. Efterfølgende samtaler de om deres oplevelser og iagttagelser. Det er i denne samtale vigtigt, at der også her tilstræbes ligeværdighed eller principiel symmetri (kollegaskab) mellem de deltagende samtalepartnere. Ingen af deltagerne bør således kunne påberåbe sig "patent« på en "sandhed « om den gennemførte undervisning (http://www.puc.aau.dk/Adjunkt2005/supervision/Vejledning_supervision_2005. pdf).

Interaktionen kan som nævnt også gøre underviseren/vejlederen til referencepunkt for didaktiske valg, og for hvordan disse iagttages i undervisning. Denne variationsform af undervisningen tildeler underviseren rollen som mester. Og det er netop denne undervisningsform, der præger flere af landets adjunktpædagogikum. (http://www.ruc.dk/unipaed/adjunktuddannelsen/adjunktvejleder/). Eventuelt også http://www. econ.ku.dk/ispu/Materiale/ISPUnotater/notat1.pdf (side 4).

Som didaktisk teori refererer mesterlæretraditionen til en række forudsætninger, som er relevante at reflektere, når den tildeles en central betydning i et adjunktpædagogikum.

Mesterlæretraditionen baserer sig for det første på en antagelse om en endelig og tilstrækkelig kundskabsmængde, nemlig det mesteren ved ${ }^{6}$. Denne præmis vil formodentlig være uproblematisk inden for områder, som kendetegnes ved et relativt stabilt kundskabsfelt. Det vil sige et felt, hvor det med en rimelig sikkerhed kan besluttes, hvilke valg der er mest hensigtsmæssige, og det tidsmæssigt kan forventes, at det, der fungerede i går, også fungerer i morgen.

Jeg vil dog stille spørgsmålstegn ved, om denne antagelse holder i universitetsundervisning. Som jeg ser det, forandrer det kundskabsfelt, som didaktiske valg må referere til, sig hastigt i mindst to retninger. Dels hvad angår undervisningens indhold (faget), dels hvad angår didaktisk viden. Det vil sige, at adjunkten for at være kvalificeret til fremtidig universitetsundervisning ikke blot skal kunne mestre, hvad vedkommende selv eller vejlederen har og har haft succes med, men kunne træffe begrundede valg af undervisningsmål, indhold, metoder, medier og evalueringsformer i undervisning, som på endnu ukendte måder er forskellig fra den aktuelle. Uanset hvor erfaren og kompetent den faglige vejleder er som underviser - og det er vigtigt at understrege, at jeg ikke har nogen som helst grund til at betvivle vejledernes kompetencer - kræver det at bidrage til en sådan kompetenceudvikling langt mere og andet end, at vejlederen altovervejende vejleder med egen praksis som referencepunkt, sådan som mesterlærens grundlæggende princip lægger op til.

Den mesterlærelignende vejledning, hvor adjunkten iagttager sig selv som underviser gennem vejlederen, kan illustreres som en deformering af den didaktiske trekant ${ }^{7}$.

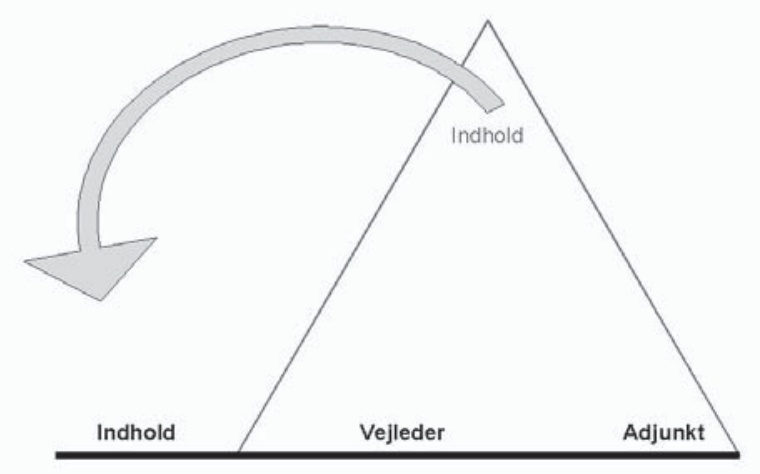

Figur 2. Mesterlare illustreret som anomali af den didaktiske trekant. Begrebet anomali er hentet fra Diederich (1988:256).

\section{Mesterlære og kommunikativ kompleksitet}

En anden grund til at problematisere mesterlæreprincippet i adjunktpædagogikum hænger sammen med måden, hvorpå mesterlæren forholder sig til kompleksiteten i sociale systemer. Uanset om blikket rettes mod 
den oprindelige mesterlære eller mod nogle af de nyere forsøg på at modernisere mesterlæren (Nielsen \& Kvale 1999), er det tydeligt, at undervisning forstås som et simpelt handlingssystem. Det betyder, at beskrivelser af og refleksioner over undervisning baserer sig på en antagelse om, at hvis adjunkten - eventuelt i overensstemmelse med vejlederens anvisninger - fremover handler anderledes - vil de studerende også handle anderledes. Enhver, der har gentaget et undervisningsforløb, har sikkert oplevet, at selv om man som underviser stort set gør det samme (holder det samme oplæg, gennemfører de samme øvelser, stiller de samme spørgsmål), kan de to forløb udvikle sig meget forskelligt. Undervisningen - og dermed også undervisningens kvalitet - synes med andre ord ikke entydigt og kausalt at kunne tilregnes underviserens kommunikative handlinger.

Derfor er det relevant at inddrage en refleksionsteori, som kan beskrive undervisningens uforudsigelighed som andet end funktionsfejl hos enten underviser eller lærende. Denne mulighed tilbyder Luhmann gennem sin beskrivelse af sociale systemer som funktionelt lukkede, selvproducerende (autopoietiske) systemer. At beskrive sociale systemer på denne måde har den konsekvens, at kommunikation henviser til forudgående valg af meddelt information og valg af forståelse; det vil sige til kommunikationen selv. Hvordan kommunikationen udfolder sig kan derfor ikke tilskrives de enkelte bidrag og dermed deltagerne, men formes af, hvordan kommunikative valg henviser til og følger efter hinanden. Gennem kommunikationsbegrebet fremtræder sociale systemer endvidere som dobbelt-kontingente (dobbelt-ubestemte) systemer, hvor dobbeltkontingens henviser til, at samtlige deltagere kan og til enhver tid vil kunne have handlet anderledes. (Luhmann 1995b; Luhmann 2000:149-154).

Med adjunkten som iagttagelsespunkt betyder det, at vedkommende i en konkret situation kan træffe andre didaktiske valg og handle anderledes, uden at de studerende eller den observerende adjunktvejleder ændrer forståelse og opfattelse af undervisningen. Eller adjunkten kan gentage didaktiske valg, som de studerende eller vejlederen opfatter på en anden måde, end de gjorde tidligere. I forhold til adjunktpædagogikum sætter det at anvende Luhmann som refleksionsteori således fokus på, at undervisningskvaliteten ikke kausalt kan tilskrives adjunktens beslutninger og handlinger. Ganske enkelt fordi en række af de kommunikative valg ligger uden for adjunktens indflydelse.

På den måde adskiller det at lære sig at undervise og at træffe didaktiske valg sig grundlæggende fra de systemer, der er referencepunkt for mesterlæren som didaktisk princip. Undervisning handler jo netop ikke om omgang med objekter, som opfører sig forudsigeligt, men om etablering og opretholdelse af komplekse og dynamiske kommunikationssystemer, som ikke kan kontrolleres af nogen af deltagerne.

Mesterlære som didaktisk teori fremstår således som problematisk, både hvad angår forståelse af undervisningens kundskabsfelt, og hvad angår kompleksitetsfølsomheden i forståelse af undervisning som interaktion.

Der er næppe nogen tvivl om, at erfarne undervisere kan fremdrage masser af erfaringer, som adjunkter og andre mindre øvede undervisere kan have glæde af at høre, se og diskutere. At benytte sig af denne mulighed medfører dog ikke automatisk, at interaktionen rammesættes som mesterlæreprincippet. Reich foretager således en skelnen mellem underviseren som bedrevidende og underviseren som merevidende og gør forskydningen fra den bedrevidende til den merevidende til et grundpostulat for sin didaktiske ansats, samtidig med at hun fastholder relationen mellem underviser og lærende som undervisningens moment (Reich 2000:264, 267).

Måske kendetegner denne mere symmetriske relation allerede den praktiske vejledningsinteraktion mange steder, men hvis adjunktpædagogikum skal etableres og gennemføres uden alt for store indre modsætninger, fordrer det, at også uddannelsesforløbets beskrivelser af interaktionen samt deltagernes roller og opgaver justeres i forhold hertil. Et første oplagt skridt herhenimod er, at mesterlæren afvikles og erstattes med en undervisningsform, hvor referencepunktet på interaktionsaksen forskydes i retning af den lærende; det vil sige adjunkten. Herudover ligger der en udfordring $i$ at håndtere eller opløse de usikkerheder til relationen mellem adjunkt og vejleder, som jeg berører i artiklens første del, og som jeg ser som en afgørende årsag til, at adjunkter forholder sig refleksivt til grænsen mellem tillid og mistillid i vejledningsrelationen

\section{Praktiske implikationer og perspektiver}

Den foreslåede forskydning af referencepunktet for adjunkt-vejleder-interaktionen i retning af adjunkten kan enten ske ved at bibeholde undervisning som konditionerende forskel eller basere sig på en ændring af kommunikationens konditionering fra undervisning/- til kolle$\mathrm{ga} /$-. Hvis undervisning fastholdes som konditionerende forskel, vil jeg tale om, at det paradoks, som adjunkterne for indeværende oplever mellem interessen i en tematisk åben og reflekterende interaktion med deres faglige vejleder og ønsket om at sikre sig selv en god bedømmelse, håndteres. Hvis bedømmelsesaspektet helt fjernes fra vejledningsrelationen, således at denne entydigt konditioneres gennem forskellen kollega/-, vil jeg tale om, at paradokset oploses gennem rekontekstualisering.

Så længe adjunktvejledningen skal fokusere på både kollegial sparring og bedømme adjunkten, vil der, for mig at se, være en oplagt risiko for, at i hvert fald adjunkten konditionerer interaktionen som undervisning/- og bedømmelse/-. Den sanktionerende bedømmelse fra kollegial side må altså opgives, for at kommunikationen mellem adjunkten og en person fra 
fagmiljøet entydigt kan udfolde sig på de præmisser, der kendetegner kollegiale relationer.

Opløsning af paradokset gennem rekontekstualisering vil derfor kræve, at bedømmelse flyttes fra adjunktens faglige miljø over i adjunktpædagogikum, og at adjunktpædagogikum både beskriver det aktuelle bedømmelsesgrundlag samt formulerer transparente bedømmelseskriterier.

Det, at bedømmelsen ligger hos vejlederen, kan være en medvirkende årsag til, at adjunkterne på AAU udtrykker usikkerhed om relationen til vejlederen, uagtet at den fra adjunktpædagogikums side beskrives som kollegial og symmetrisk. (http://www.puc.aau.dk/Adjunkt2005/supervision/Vejledning_supervision_2005. pdf).

Lidt skarpere udtrykt vil jeg sige, at AAUs adjunktpædagogikum måske endda installerer en åbenlys og ganske markant tvetydighed $i$ adjunktvejledningen ved at insistere på symmetri og sanktionsgivende bedømmelse i en og samme vejledningsrelation.

For at bevare adjunktens mulighed for at drage nytte af erfarne kollegers kundskaber synes det vigtigt at legitimere adjunktens adgang til didaktisk kollegial refleksion, således at muligheden for didaktisk sparring ikke kommer til at bero på kollegial velvilje. Derfor bliver det relevant at formalisere interaktionen og de hertil knyttede personrelationer gennem yderligere forskelle end blot kolleger/alt andet. Et bud på dette kunne være at trække på den systemiske supervisions begreber om reflekterende team. Ideen bag reflekterende teams er, at nogle få personer - eventuelt kun en enkelt - observerer en given situation og tilbyder deres iagttagelser af og overvejelser om situationen til deltagerne. Deltagerne kan så spejle både sig selv og interaktionen i disse beskrivelser (Schilling, 1997). I dette perspektiv kan interaktionen konditioneres som didaktisk refleksion, og den erfarne kollega tildeles rollen som didaktisk spejl. En anden mulighed er at vende blikket mod supervisorbegrebet. Interaktionen vil da kunne konditioneres som supervision, og relationen mellem kollegaen og adjunkten etableres i overensstemmelse hermed som supervisor/supervisand. En tredje mulighed er at se nærmere på mentorbegrebet.Ved at konditionere interaktionen som en mentorordning vil relationen mellem den tilknyttede person fra det kollegiale miljø og adjunkten konstitueres gennem forskelle mentor/mentee. Jeg vil ikke her foretage yderligere analyse af forudsætninger og implikationer af at vælge en af disse tre forskelle til brug for yderligere konditionering af kollegarelationen. Dog synes det indlysende, at uanset hvilke forskelle, der anvendes til beskrivelse af betingelserne for interaktionen og de tilhørende roller, må disse ledsages af præciseringer af de forventninger, som adjunktpædagogikum knytter til en interaktion, der udfolder sig inden for den aktuelle forskel, herunder afklaring af deltagernes roller. Helt oplagt synes rollen som didaktisk spejl at antyde en langt større rolle- og kundskabsmæssig symmetri mel- lem deltagerne end en rolle som mentor.

Endvidere må blikket ved en sådan genbeskrivelse rettes mod både intenderede og ikke-intenderede følgevirkninger af de didaktiske valg.

Vælger man i stedet at søge at håndtere problemet, fastholdes kommunikationen mellem adjunkt og vejleder som undervisning med afsluttende bedømmelse. Udfordringen for adjunktpædagogikum bliver da for det første at få etableret en større faglig symmetri, som kan bidrage til at ophæve den blokering for en fælles udforskning af adjunktens undervisning, der etableres gennem mesterlæreprincippet (jf. deformeringen af den didaktiske trekant). Konkret betyder det, at adjunktens didaktiske viden og valg må tildeles større betydning i såvel vejledning som bedømmelse. For det andet må bedømmelsesgrundlaget ændres fra vejlederens personlige vurdering til transparente kriterier formuleret af adjunktpædagogikum. I forbindelse hermed synes det afgørende for udvikling af didaktiske kompetencer, som sætter adjunkten $i$ stand til at varetage fremtidens endnu ukendte undervisning, at vurderingskriterierne forskydes markant fra vurdering af adjunktens aktuelle præstationer til vurdering af adjunktens didaktiske kompetencer i meget bred betydning, hvor der fokuseres på både teoretiske refleksionskompetencer, kompetencer for begrundet planlægning, gennemførelse, evaluering og justering af undervisning.

\section{Litteraturhenvisninger}

Dewey, John (1996). Erfaring og opdragelse. København: Chr. Ejlers Diederich, Jürgen (1988). Didaktisches Denken. Eine Einführung in Anspruch und Aufgabe, Möglichkeiten und Grenzen der Allgemeinen Didaktik. Weinheim; München: Juventa (Grundlagstexte Pädagogik)

Keiding, Tina Bering (2002). Portefoljer. Et operativt konstruktivistisk perspektiv på en undervisningsmetodik og dens laringspotentiale. Aalborg:Videncenter for Læreprocesser (nu Institut for Uddannelse; Læring og Filosofi), Aalborg Universitet

Keiding, Tina Bering (2005). Hvorfra min verden går. Et Luhmanninspireret bidrag til didaktikken. Ph.d.-afhandling. Aalborg: Aalborg Universitet, Institut for Uddannelse, Læring og Filosofi, http://www.learning.aau.dk/dk/forskning/publikationer/phdafhandlinger.htm

Keiding, Tina Bering \& Laursen, Erik (2005). Interaktion og Laring. Gregory Batesons bidrag. København: Unge Pædagoger

Klafki, Wolfgang (2001). Dannelsesteori og Didaktik - nye studier. Århus: Klim

Künzli, Rudolf (1998). The Common Frame and the Places of Didaktik. Gundem, Bjørg B. \& Hopmann, Stefan (eds.): Didaktik and/or Curriculum: an international dialogue. New York: Peter Lang Publishing

Künzli, Rudolf (2000). German Didaktik: Models of Re-presentation, of Intercourse, and of Experience. Westbury, Ian, Hopmann, Stefan, Riquarts, Kurt (eds.): Teaching as a Reflective Practice. The German Didaktik Tradition. London: Lawrence Erlbaum Associates

Lave, Jean \& Wenger, Etienne (1991). Situated Learning - Legitimate Peripheral Participation. Cambridge: Cambridge University Press

Luhmann, Niklas (1995a). Begyndelser og Slutninger. Betragtninger over forskellene. Jacobsen, Jens Christian (red): Autopoiesis IIudvalgte tekster af Niklas Luhmann. København: Politisk revy

Luhmann, Niklas (1995b). Was ist Kommunikation. Luhmann, Niklas: Soziologische Aufklärung, Bd. 6. Die Soziologie und der Mensch. Opladen: Westdeutscher Verlag 
Luhmann, Niklas (1999). Tillid - en mekanisme til reduktion af social kompleksitet. København: Hans Reitzel

Luhmann, Niklas (2000). Sociale systemer - grundrids til en almen teori. København: Hans Reitzel

Luhmann, Niklas (2002). Das Erziehungssystem der Gesellschaft. Frankfurt am Main: Suhrkamp

Luhmann, Niklas (2004 (1986)). Codierung und Programmierung: Bildung und Selektion im Erziehungssystem. Niklas Luhmann: Schriften zur Pädagogik. Frankfurt am Main: Suhrkamp

Munk, Merete (2002) Mesterlare retur. København: Unge Pædagoger

Möller, Christine (1999). Die curriculare Didaktik. Herbert Gudjons \& Rainer Winkel (Hg.): Didaktische Theorien. Hamburg: Bergmann+Helbig

Nielsen, Klaus \& Kvale, Steinar (1999) (red.). Mesterlare som social praksis. København: Hans Reitzel

Reich, Kersten (2000). Systemisch-konstruktivistische Pädagogik. Neuwied, Kriftel: Hermann Luchterhand

von Cube, Felix (1999). Die kybernetisch-informationstheoretische Didaktik. Gudjons, Herbert \& Winkel, Rainer (Hg.): Didaktische Theorien. Hamburg: Bergmann+Helbig

\section{Noter}

1 Der er forskelle i, hvilke betegnelser der anvendes. Nogle steder anvendes både betegnelsen supervisor og vejleder, andre steder kun en af betegnelserne. Da vejleder er en gennemgående betegnelse, har jeg valgt kun at bruge den.

2 Disse udsagn er kun i meget begrænset omfang citater, der kan henføres til enkeltpersoner. Det er min formulering af temaer, som jeg har bidt mærke i som kursusholder, workshopleder og vejleder.

3 Organisation anvendes her - i overensstemmelse med Luhmanns begreber - som betegnelse for et socialt system, som afgrænser sig fra omverdenen via medlemskab (Luhmann 2000,240). Organisation kan altså her henvise både til et forskningsteam, en faggruppe, gruppen af videnskabeligt personale, instituttet eller institutionen.

4 Gregory Bateson beskæftiger sig flere steder i sit forfatterskab med forholdet mellem kontekst og det, han betegner som kontekstens kontekst. Hans mest kendte bidrag til denne tematik er formodentlig teorien om 'double-bind', som beskriver den ulykkelige situation, der kan opstå, når det ikke er muligt for et individ at skabe mening $i$ en interaktion præget af modsatrettede signaler gennem konstruktion af en konteksternes kontekst, som angiver, hvordan enkelte hændelser skal relateres til hinanden (Keiding \& Laursen 2005).

5 Uagtet at mesterlære nogle steder opfattes som en læringsteori, ser jeg det som en didaktisk teori, da mesterlæreteorierne udelukkende beskæftiger sig med beskrivelse af en 'læringsbefordrende omverden' for den lærende.

6 I nyere mesterlæreteorier erstattes flere steder mesteren helt eller delvis med praksisfællesskabet (Nielsen \& Kvale 1999). Dette ændrer dog ikke ved de grundlæggende præmisser om et endeligt kundskabsfelt.

7 I Diederich $(1988,256)$ anvendes forskellige variationsformer af den didaktiske trekant til at illustrere forskellige former for undervisning. En række af disse, heriblandt den hvor underviseren skygger for indholdet, betegnes som anomalier. 